\title{
ESTIMATE FOR THE DISCRETE TIME HEDGING ERROR OF THE AMERICAN OPTION ON A DIVIDEND-PAYING STOCK
}

\author{
SUlTAN HUSSAIN AND NASIR REHMAN
}

Abstract. This work is devoted to the discrete time hedging of the American option on a dividendpaying stock with a convex payoff, the particular case of which is American call option. Perfect hedging requires continuous trading in time and knowledge of the partial derivative of the value function of the American option in the underlying asset. Neither one can trade continuously in time nor the closed-form expression of the value function of the American option is known.

Several approximation methods have been developed for the calculation of this unknown value function. We justify in this work that having at hand any such nonnegative uniform approximation, it is possible to construct a discrete time hedging strategy the value process of which uniformly approximates the value process of the corresponding continuous time perfect hedging portfolio.

Mathematics subject classification (2010): 60J75, 60G40, 60J60.

Keywords and phrases: American option; discrete time hedging; hedging error; optimal stopping problem; locally Lipschitz functions.

\section{REFERENCES}

[1] N. El-Karoui, M. Jeanblanc-Picqué and S.E. Shreve, Robustness of the Black and Scholes formula, Math Finance, 8, 2 (1998), 93-126.

[2] R. Glowinsky, J.L. LiOns And R. TrÉmolières, Numerical Analysis of Variational Inequalities, Amsterdam: North-Holland Publishing Company, New York, 1981.

[3] D.G. HoBSON, Volatility misspecification, option pricing and superreplication via coupling, The Annals of Applied Probability, 8, 1 (1998), 193-205.

[4] S. Huss ain And M. Shashiashvili, Discrete Time Hedging of the American Option, Mathematical Finance, 20, 4 (2010), 647-670.

[5] S. Hussain, J. PeČArić And M. Shashiashvili, The Weighted Square Integral Inequalities for the First Derivative of the Function of a Real Variable, Journal of Inequalities and Application, Article ID 343024 (2008) doi:10.1155/2008/343024.

[6] P. Jaillet, D. Lamberton And B. LAPEy Re, Variational Inequalities and the Pricing of American Options, Acta Applicandae Mathematicae, 21, 3 (1990), 263-289.

[7] E.R. JAKOBSEN, On the rate of Convergence of Approximation Schemes for Bellman Equations Associated with Optimal Stopping Time Problems, Math. Models Methods Appl. Sci. (M3AS), 13, 5 (2003), 613-644.

[8] Karatzas, I. And S.E. Shreve, Brownian Motion and Stochastic Calculus, Springer-Verlag, 2nd Edn., New York, 1991.

[9] Karatzas, I. And S.E. Shreve, Methods of Mathematical Finance, Springer, New York, 1998.

[10] D. Lamberton and S. Villeneuve, Critical Price Near Maturity for an American Option on a Dividend-Paying Stock, The Annals of Applied Probability, 13, 2 (2003), 800-815.

[11] H. L. Royden, Real Analysis, Prentice-Hall of India, New Delhi, 1997.

[12] S.E. Shreve, Stochastic Calculus for Finance II, Springer, New York, 2004.

[13] P. Wilmott, J. Dewynne And S. Howison, Option Pricing: Mathematical Models and Computations, Oxford Financial Press, Oxford, 1993. 